\title{
IMPROVING TEACHER PERFORMANCE BASED ON CREATIVE MODEL
}

\author{
Alfiatur Rohmaniyah ${ }^{1 *}$, Tatiek Nurhayati ${ }^{2 *}$
}

\author{
* Affiliation: \\ ${ }^{1,2}$ Director of Alkafi \\ Company \\ email: \\ alfiaturrohmania21@ \\ gmail.com
}

\begin{abstract}
:
This aims of the study is to describe and analyze the relationship between the effect of teacher creativity on teacher performance by work it self, innovative behavior and professional competence as an intervening variable. Based on the distribution of questionnaires to all Madrasah teachers in East Semarang who were certified by 97 , the sample of 88 respondents was obtained. The analytical tool in this researche is path analysis, where already validated and pass the reliability and classical assumptions were tested. The test results show that teacher creativity has a positive impact on work it self, innovative behavior and professional competence. The direct test results also show teacher creativity, work it self, innovative behavior and professional competence have a significant positive impact on the teacher performance. Work it self and innovative behavior also capable of being an intervening variable between teacher creativity and teacher performance. Professional competence is capable to be an intervening variable between teacher creativity and teacher performance, meaning that the higher the teacher's ability to produce new ideas in the teaching and learning process, the competence or professionalism skills of teachers will increase so that it has an impact on the teacher performance achievement maximally.
\end{abstract}

Keywords : teacher creativity, work it self, innovative behavior, professional competence and teacher performance.

\section{INTRODUCTION}

Teacher performance becomes an important thing in order to determine student's success, particularly in the relation with the teahing learning process. The important role of teacher in education field, a lot of efforts to improve the teacher quality which have done by the government, one of them is by teacher certification program. The government effort to make certification program is to create and increase the teacher performance. To create professional teacher, the government expect that after the certification is needed to make the systematic and synergies and also sustainable to guarantee the teacher to keep as a professional teacher. (Nyanyu, 2013)

The fact shows that the sertification supposes to improve the teacher innovative behaviorin tecahing learning process which showed by the improvement of teacher performance is not as expected, teachers who have passed certification do not show innovative behavior in the reality. This is due to the lack of the teacher's role in the work itself (work it self), make a process and get a qualified result of education also caused by teacher satisfaction with their work. The maximality of 
teacher performance also needed professional competence from the techer. As a professional figure, the teachera must haveexpertise in their field, such mastering the material that must be taught andthe method as well, the feeling of responsible of the duty and the feeling of togetherness with other teachers (Hartanti and Yuniarsih, 2018). Moreover, to reach the maximall of teacher performance, some factors that is needed by the teacher's creativity in teaching learning process.

Creativity in someone's capability to create something new, both idea or real work that is different from what has existed before (Juwono and Wangsadinata, 2010). Every human has their own passion or motivation from insede of them to create creativity and develop potential, disclose and activate all of its capacity to improve performance (Munandar, 2012). The encouragement is main motivation for creativity when the individual creates new relations with the environment to improve the performance.

It happens in the Madrasah teacher in East Semarang, teacher performance can not be separated from the teacher capability to reach the school expectation of the education goals. To improve the teacher's performance, the management office of the Madrasah gives instruction to their employee to be more passionate to their job, since it is precious job to create the gold generation of the nation. The management also encourages the whole teachers to have ability to produce new idea in teahing learning proccess (inovatif behavior). As well as keep improving and developing teacher professional competence while teaching learning process is running.

According to the interview with one of the educations and culture department employee from certivication management, he told that in the real condition the certivication teaher has not give significant impact yet toward the teaher professional capability belongs to improving the learning quality. Moreover, in the Kompas daily (2017) show that there are more cases which is not expected by certified teachers, whichafter receiving certification the teachers are lack of discipline and some of them thought that main goal og being a teacher. If we compared with a condition before certification program, many teachers took part in capacity building through various trainings and seminar, yet after being declared passed the certification of teachers tended to skip those activities.

According to the interview result with teachers in East Semarang School, this common phenomenon is found in teaching learning process, most of teacher was used conventional method that may cause boredom of students due to monotonous teaching methods. It means that in the teaching and learning process there are still found a low of teacher creativity in the delivering the subject, such as the using of information technique to attract the student's interest and stimulate them to more reative is in low level. It is because of the low ability of the teachers to use information technology maximally. The teacher professional competence supposes to be developing more in creating something different so it can stimulate, practice and increase student's interest to be more active in the teaching and learning process.

Another phenomenon is found that the lower teacher performance can be seen by the way she or he delivers the material which tends to be mechanistic, where students are not directly involved in practice. It is because the teacher's competence is low in responding to the activity of students in the teaching and learning process. Less of creativity to use learning 
media such through mass media is a less interesting cause in the learning process. In realty the use of mass media such as television, internet and others in learning, internet and so on inteachng learning process contains a loto $\mathrm{f}$ useful value for students.

However, the research about teaher performance already done by many researchers before, as like done by Munandar (2009) and Putri (2013) that employee creativity influences employee performance. The results of similar studies were also conducted by Adirestuty and Wirandana (2016) and Dama and Ogy (2018) which showed that creativity had a positive effect on employee performance. In contrast to the research conducted by Lakoy (2015), creativity actually did not affect employee performance.

\section{LITERATURE REVIEW}

Based on the background of the study, the teacher's performance is less than optimal, so the formulation of the problem in this study is how the efforts made by the Madrasah School Principals so that the performance of the teachers can increase. Based on these problems, the esearch question of this study is how the teacher creativity influence toward teacher performance with work it self, innovative behavior and professional competence as intervening variable?

\section{Teacher Performance}

Performance refers to the level of success of carrying out tasks and the ability to achieve the goals (Donelly, Gibson and Ivancevich, 1994). While Hasibuan (2012) defines performance as a result of work achieved by someone in carrying out the tasks assigned to him.which is based on skills, experience, sincerity, and time

Teacher performance is an activity in a teaching learning process that is how the tecaher plans, applys the learning process and scoring the outcomes (Regulation of Republic Indonesia No. 41 tahun 2007). According to Hamzah Uno (2013) teacher performance is a describtion of the work which done by educators in relation to the tasks they carry out and responsibility with. Furthermore, Adebola (2000) in Hartanti and Yuniarsih (2018) define the teacher performance as a measurement of the level of effectiveness that is expected.

Mangkunegara (2012) states that performance indiators can be seen from thequality, quantity, implementation of duties, and responsibilities. Quality of work is how good a teacher does the obligaton. The quantity of work is how long a teacher works in one day. The quantity of work can be seen from the speed and reliability of the teacher in the teaching and learning process. Task Implementation is how far the teacher is able to do his job accurately or there are no mistakes. Responsible with the job is awareness of the obligation of employees to carry out the work given by the school. While according to Riduwan (2009) the teacher performance can be measured by planning teaching and learning process and evaluating learning outcomes.

\section{Teacher Creativity}

Accrding to Munandar (2012) creativity is an ability to create new ombination, based on the data, information or the elements exist. The results created are not always new things, but can also be a combination (combination) of things that already existed before. The results created are not always new things, but can also be a combination (combination) of things 
that already existed previously. Moreover, Csikszentmihalyi (in Clegg, 2008) mentions that creativity as an ation, idea, or a product that replaces something old into something new.

According to Mulyasa (2003) in Hartanti and Yuniarsih (2018) creativity is something that is universal and characteristic of aspect of our world. Teacher creativity is a very important thing to demonstrate and show that creativity.The teacher realizes that creativity is universal and therefore all activities are sustained and dimmed and awakened by consciousness.

Creativity plays important role in teaching and learning proess. So, the teacher is required to demonstrate and show the process ofcreativity greatly in the teaching and learning process. Based on Guilford (1988) in Adirestuty and Wirandana (2016) explain that there are some aspects that underlie the characteristics of one's creativity, including the smooth of thinking, flexibility of thinking, elaboration and originality.

\section{Work it Self}

Work it selfrelates to a someone's feelings or attitudes about the job itself, salary, promotion or education opportunities, supervision, coworkers, job-responsiilities, etc(Hughes, 5012). Furthermore, in(Tunjungsari, 2011) defineswork it selfas a emotional ondition or positive emotional which come from evaluating of someone's work.

Work it selfis a pleasant or unpleasant emotional state of the job. Work it self reflect someone's feelings towards his job(Kurniawan, 2013). Handoko (2012) explain that work it selfas a pleasant or unpleasant emotional state for employees to see their job. Work it self reflect someone's feeling to his job. Siagian (2014) also mention that work it self is someone's positive or negative toward their job.

According to Luthans (2005) the indicators of the work itself can be seen as follow:

1. Feeling of useful, the cognitive state includes the degree to which employees feel their work can be useful, important and valuable contributions. Employees feel that the work they do has very important value so that employees will work seriously.

2. Responsibility, which is a condition that means how employees feel personal responsibility for their work. Employees will have a sense of responsibility for the work they have done.

3. Knowledge of results, continued direct feedback, a state of psychology that involves the degree to which employees are able to understand how their performance results from their work. Aim to know the extent of the employee's performance.

\section{Innovative Behavior}

According to Van de Ven (1986) din Wiendiasih and Etikariena (2017), the development and application of new ideas by individuals were involved in interactions in an organizational structure. The new idea in question can be a combination of previous ideas, sebuah rencana untuk memenuhi tantangan saat ini. The process of innovation that occurs in an organization involves all individuals in the organization. In this case, the individual takes role in develop, carry, respond and modify the idea.

De Jong and Kemp (2003) mention that innovation can be interpreted as all individual actions directed at the interests of the organization, whih the introduction and application 
of new ideas are beneficial. Innovative behavior is a consequence of a number of individual perceptions and attitudes (Hult, et.al, 2004).

According to the instrument developed by Prayudhayanti (2014), innovative behavior can be measured, among others, by generating new ideas, new opportunities, useful for work, utilizing everything in the environment and seeking new information and knowledge. While according to Hult, et.al (2004) as the instrument develops by Wiendiasih and Etikariena (2017), the innovative behavior can be measured by generalization idea, promotion idea, realization idea.

\section{Professional Competence}

Spencer and Spencer in Palan (2008) shows that competence shows behavioral characteristics that describe motives, knowledge or expertise, personal characteristics, values and skills. This professional competence aims to improve proactive behavior in bringing change and increasing people's intelligence to anticipate future developments and changes (National Library of RI 2013).

Raharjo and Sutomo (2016) explain to measure the professional competene can be used with mastery of material, mastery of competency standards, developing professionalism on an ongoing basis, and the use of information technology. While according to Davis and Thomas (1989) as in Hartanti and Yuniarsih (2018) have grouped teacher professional competencies into four group, they arethat professional competence can be measured, among others, by the ability to create a learning climate, management learning strategies, giving feedback, reinforcement,and having abilities related to self-improvement.

\section{Relation of Each Variable}

\section{The Effects of Teacher Creativity on Work it Self}

Creativity is connecting and rearranging knowledge in human minds that allow themselves to think more freely in generating new things or generating ideas that surprise others in producing useful things (Evans, 1994 in Sya'roni, 2017).Creativity is indirectly related to the ability to carry out different ideas and is also sensitive to the environment because someone is satisfied with the work he does. It means that the ability to show up new ideas because someone has an interest in the work itself. Thus, the higher of teacher's creativity, the ability to create new ideas in the teaching and learning process will increase so that it will further increase the teacher's satisfaction with the work itself.

Thus, appropriate with Roger statement (2002) as what develoed by Munandar (2012) each individual has a passion or encouragement from within to be creative, realize about the potential, reveal and activate all the capacity he has because of the satisfaction of his work.

The results of research conducted by Munandar (2012) and Wibisono (2015) show that teacher creativity influences job satisfaction. Likewise with Lakoy's research (2015) that work creativity has an effect on job satisfaction which is proxied by work it self. Based on the empirical studies, hypothesis proposed as follow:

$\mathrm{H}_{1}$ : Teacher creativity give a positive effect toward work it self 


\section{The Effect of Teacher Creativity toward the Innovative Behavior}

The good Management creativity is a challenge and necessity for organizations to win the competition. So that creativity can be an investment for organizations, it can be able to develop the knowledge of each of their jobs because energy in special fields requires knowladge to bring creativity. Creativity in individuals that refers to the development of knowledge, intellectual abilities, thinking styles, satisfaction, motivation, personality will make the idea of creativity of individual behavior innovative which emerges from new ideas. Thus, creativity becomes a tool to show the innovations up that support the success of the organization. The higher the creativity of the teacher, it can be strength due to it is able to create innovative behavior that can create and adopt ideas or new ways to be applied in the teaching and learning process.

It based on the Timpe statement (1999) in Aprilliyani (2016), creative employees who refer to the development of individuals in developing new ideas, products and procedures that are useful for the organization are raw materials because they are able to create innovative behavior.

The results of the research conducted by Aprilliyani (2016) show that employee creativity has a positive effect on innovative behavior. While the research of Kumalasari and Sya'roni (2017) Dama and Ogi (2018) show that creativity influences innovative sustainability. Based on those theories and supported by previous research, the following hypothesis can be formulated:

$\mathrm{H}_{3}$ : teacher creativity has a positive impact toward the profesioanl competence.

\section{The Effect of Teacher Creativity toward the Teacher Performance}

The creative teacher is kinds of human resources that is needed in the process of teaching and learning. Due to the creative teacher will be able to produce new ideas, so it is strongly needed in teaching learning process.

The higher of teacher creativity, then the ability to produce new ideas in the teaching and learning process will increase, however it will have an impact on achieving teacher performance maximally.It is accordance with the statement of Roger (Munandar, 2009) that each individual has a tendency or drive from within him to be creative, realize the potential, reveal and activate all the capacities he has in order to improve performance

Guiford (in Munandir, 2009) states that creativity is the ability of divergent or exploring thinking $\mathrm{n}$ various alternative answers to a problem $\mathrm{n}$ equal truth (Guilford, in Munandar 2009). While according to (in Zulkarnain, 2002), creativity is human tendencies to actualize themselves according to their abilities. The results of research conducted by Munandar (2009) and Putri (2013) showed that employee creativity had an effect on employee performance. The research results from Adirestuty and Wirandana (2016) and Dama and Ogy (2018) also show that creativity has a positive effect on employee performance

In contrast to the research conducted by Lakoy (2015) that creativity actually does not affect employee performance.

$\mathrm{H}_{4}$ : Creativity has positive effect toward the teacher performance 


\section{The Effect of Work it self Toward the Taecher Performance}

Work it selfcan be elaborated as a pleasant or unpleasant emotional state of someone in looking at the work itself.Teacher satisfaction with the work depends on what the teacher wants or the job and outcomes of the teaching and learning process. Teachers who are satisfied with their work will try to give the best to their students in learning process. Teachers with a high level of job satisfaction on the work they do will do everything possible without any burden or pressure, so work is please. Teachers, who feel satisfied with their work, will try to work optimally and improve their performance and strive to excel. It based on the Handoko (2012), job satisfaction through work itself is an evaluation or reflection of workers' feelings for their work. The size of employee job satisfaction on the work it self is closely related to the performance produced.The results of this study support the results of research conducted by Satriowati et al. (2016) that work it self has a positive and significant effect on employee performance. So does the case of Fitrianasari's research, et.al (2016) that work itself has a positive and significant effect on HR performance. Based on the theory and supported by previous research, the hypothesis can be formulated as follows:

$\mathrm{H}_{5}$ : Work it selfhas a positive effect toward the teacher performance

\section{The Effect of Innovative Behavior toward the Tecaher Performance}

Innovative behavior is an individual action to create and adopt thought ideas or new ways to be applied in the implementation and completion of work (Gaynor, 2002 as developed by Prayudhayanti, 2014).

Innovative behavior arises when a teacher faces challenges in his work and gets broad authority in carrying out his duties and responsibilities.Thus, the higher innovative behavior, the teacher's role in creating and adopting ideas in the teaching and learning process is also higher, so that the teacher's performance can be maximized. It is based on Wallace, et al. (1999) in Prayudhayanti (2014) statement that innovative work behavior (innoavative behavior) becomes an important part of improving someone's performance in preparing competitiveness

The results of the previous research conducted by Khodijah and Fatah (2016) showed that innovative behavior has a positive effect on teacher performance. Similar results show that innovative behavior plays a major role in improving the performance produced as well.

$\mathrm{H}_{6}$ : Innovative Behavior has Positive effect towards Teacher Performance

\section{The Effect of Profesional Competence toward the Teacher Performance}

Professional competence is a set of abilities of a person's in carrying out tasks so that they are carried out with high quality, the right time, accurate.Ability shows the potential of people to carry out work, maybe that ability is implemented or maybe not.The work ability of the employee can be in the form of education and skills. it has an important role in solving problems. The higher professional competence, the level of ability or skill of teachers will get higher so that it will have an impact on achieving teacher performance maximally in teaching and learning precess. 
This is related with Sedarmayanti's statement (2010) that professional competence is a pillar that will place the bureaucracy as an effective machine for the government and as a parameter of apparatus skills in achieving one's performance.

Charles (2000) in Ibrohim (2016) elaborate thatcompetence is action to reach the goal which is required with expected condition.Professional competence is one of the factors that affect employee performance. it is the potential of employees to carry out work that is charged to him effectively, efficiently and responsibly. By the reason, the work ability of employees has a significant role in solving problems that occur.

The results of the research done by Subari and Riady (2015) showed that individual competencies have a positive effect on employee performance. While the research of Ibrohim (2016) and Haryaka (2016) also shows the same thing that professional competence influences teacher performance. Based on the above theory and supported by previous research, the hypothesis can be formulated as follows:

$\mathrm{H}_{7}$ : professional competence has a positive effect toward the teacher performance

\section{Research Empiric Model}

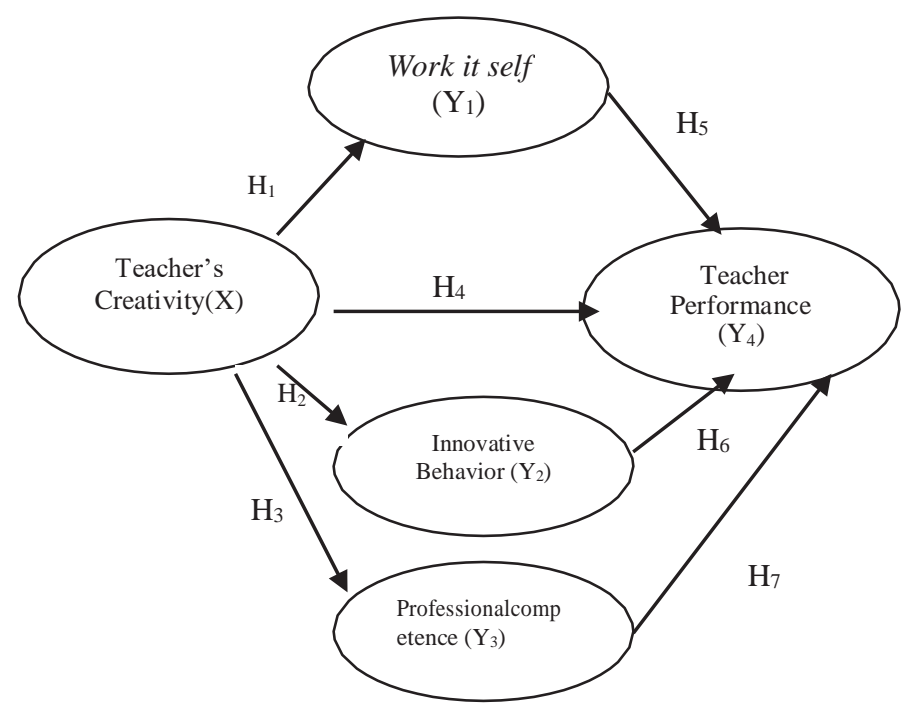

\section{RESEARCH METHOD}

The questionnaire in this research is done for the whole certified teacher of Madrasah in East Semarang with total number 97, and use sample 88 responden. The method of data analysis is done by quantitative analysis test with path analysis as analysis tool where previously passed the validity and reliability test as well as testing the classical assumption requirements. With regression equality:

$$
\begin{aligned}
& Y_{1}: b_{1} X+e_{1} \\
& Y_{2}: b_{2} X+b_{3} Y_{1}+e_{2} \\
& Y_{3}: b_{4} X+e_{3} \\
& Y_{4}: b_{5} X+b_{6} Y_{1}+b_{7} Y_{2}+b_{8} Y_{3}+e_{4}
\end{aligned}
$$


Information

$\mathrm{Y}_{1}=$ Work it self

$\mathrm{Y}_{2}=$ Innovative Behavior

$\mathrm{Y}_{3}=$ Profesional Competence

$\mathrm{Y}_{4}=$ Teacher performance

$\mathrm{X}=$ Tecaher Creativity

$\boldsymbol{\beta}=$ Regression Coeffecient

$\mathrm{e}=$ Regression error

\section{RESULT}

Table 2

Result Summary

\begin{tabular}{|l|c|c|c|}
\hline \multicolumn{1}{|c|}{ Variable } & B & T & Sig \\
\hline KG $\longrightarrow$ WIS & 0,639 & 7,702 & 0,000 \\
& 0,743 & 10,287 & 0,000 \\
KG $\longrightarrow$ PI & 0,691 & 8,65 & 0,000 \\
KG— KP & & & \\
\hline KG— KTeacher & 0,261 & 3,036 & 0,003 \\
WIS— $\longrightarrow$ KTeacher & 0,310 & 4,713 & 0,000 \\
PI — KTeacher & 0,207 & 2,760 & 0,007 \\
KP— $\longrightarrow$ KTeacher & 0,279 & 4,086 & 0,000 \\
\hline
\end{tabular}

\section{Hypotesis Test}

\section{the Effect of teacher Creativity toward Work it Self}

The test results for the teacher's creativity variable on work it self obtained t count value of 7.702 with a significance of 0.000 . In the degree of freedom of 86 , then the number of $t$ tables is 1.988 , so the value of $t$ aritmathic is 7.702> 1.988. The explanation can be interpreted that the test is able to accept Ha which means that the teacher's creativity has a positive and significant effect on work it self. Based on the results of the test it can be concluded that the test is able to accept $\mathrm{H} 1$, so that the presumption of a significant positive effect between teacher creativity on work it self is proven

\section{The Effect of Teacher Creativity toward Innovative Behavior}

Based on the test results for teacher creativity variables on innovative behavior, the value of $t$ arithmetic is 10.287 with a significance of 0.000 , so the value of $t$ count is $10.287>$ 1.988. This explanation can be interpreted Ha accepted, which means that teacher creativity has a positive and significant effect on innovative behavior. Thus it can be concluded that testing is able to accept $\mathrm{H} 2$, so that the Hypotesisis proven

\section{The Effect of Teacher's Creativity Toward the Profesional Competence}

The test results of the teacher's creativity on professional competencies obtained tarithmetic value of 8.865 with a significance value of $0,000<0.05$. Thus, the value of $t$ arithmetic 
is $8.865>1.988$, so Ha can be interpreted as teacher creativity has a positive and significant effect on professional competence. Based on the results of testing, it can be concluded that testing is able to accept $\mathrm{H} 3$, so that the hypotesis positive and significant effect between teacher creativity and professional competence is proven.

\section{The Effecct of Teacher's Creativity toward the Teacher Performance}

The test results between teacher creativity and teacher performance obtained $t$ arimethic value of 3.036 with a significance value of $0.003<0.05$. In the degree of freedom of 83 , the number of $t$ table obtained is 2,0003 , so the value of $t$ count is 3.036> 1.989. It can be interpreted Ha accepted which means that teacher creativity has a positive and significant effect on teacher performance. Based on the test results, it can be concluded that the test was able to receive $\mathrm{H} 4$, so the hypotesis were proven.

\section{The Effect of Work it Self toward Teacher Performance}

The work it self test results on teacher performance obtained $t$ archimethic value of 4.713 and significance of $0.000<0.05$, so that the value of archimethic was 4.713>1.989, which means that and Ha is accepted. This explanation can be interpreted that work it self has a significant positive effect on teacher performance. Based on the results of the test it can be concluded that the test is able to accept H5, so that hypotesisis accepted

\section{The Effect of Innovative Behavior towards the Teacher Performance}

Based on the results of calculations that have been done between innovative behavior towards the performance of teachers, the value of $\mathrm{t}$ arithmetic is 2.760 and the significance is which means it is smaller than 0.05 , so the value of $t$ archimethic is $2.760>1.989$ which means $\mathrm{Ha}$ is accepted. This shows there is a significant positive effect between innovative behaviors on teacher performance. Based on the test results it can be concluded that hypothesis test is able to accept H6 so that the hypothesis which states the existence of a positive and significant effect between innovative behaviors on teacher performance is accepted.

\section{The Effect of Professional Competence towards Teacher's Performance}

The test results of professional competence on teacher performance obtained $t$ archimatic value of 4.086 and significance of $0.000<0.05$, so the value of $t$ archimethic was 4.086> 1.989 . The explanation can be interpreted that $\mathrm{Ha}$ is accepted, which means that there is a significant positive effect between professional competence on teacher performance. Based on the results of the test it can be concluded that hypothesis testing is able to accept $\mathrm{H} 7$ so that the hypothesis which states the presumption of a significant positive effecct between professional competence and teacher performance is accepted 


\section{Determination Coefficient test}

\section{Table 4}

Determination Coeffecient Test

\begin{tabular}{|l|c|}
\hline \multicolumn{1}{|c|}{ Variable } & $\begin{array}{c}\text { Adjusted } \\
\text { R Square }\end{array}$ \\
\hline The Effect of Teacher's Creativity towards work it self & 0,401 \\
\hline The Effect of Teacher's Creativity Towards Innovative Behavior & 0,546 \\
\hline The Effect of Teacher's creativity towards Proffesional Competence & 0,471 \\
\hline
\end{tabular}

\section{The Sobel Test}

\section{The Effet of Teacher Creativity towards the Teacher Performance with Work it Selfas Intervaning Variable}

The results of hypothesis test for the effect of teacher creativity on work it self toward teacher performance obtained a double test value of 4.805 which means that the value has exceeded the t table value of 1.96 and on two tailed probability values obtained a significance value of 0.002 which means smaller than the probability level is 0.05 , which means work it self can be an intervening variable between teacher creativity and teacher performance.

\section{The Effect of Teacher Creativity toward Teacher's Performance with Innovative Behvior as Intervaning Variable}

The results of sobel test between teacher creativity and professional competence towards teacher performance obtained a double test value of 4.644> 1.96 and on the two tailed probabilities obtained a significance value of $0.000<0.05$, which means that professional competence is able to be an intervening variable between teacher creativity on teacherperformance

The results of the sobel test between teacher creativity and innovative behavior towards teacher performance obtained a double test value of 3.006 which means that it is greater than the $t$ table value of 1.96 and the two tailed probability values obtained are $0.002<0.05$, which means innovative behavior able to become an intervening variable between teacher creativity and teacher performance

\section{The Effect of Teacher's Creativity toward Teacher Performance and Professional Competence as Interverning Variable.}

The results of sobel test between teacher creativity and professional competence towards teacher performance obtained a double test value of 4.644> 1.96 and on the two tailed probabilities obtained a significance value of $0.000<0.05$, which means that professional competence is able to be an intervening variable between teacher creativity on teacher performance.

\section{DISCUSSION}

\section{The Effect of Teacher Creativity towards Work it Self}

The test results show that the teacher's creativity towards work it self has proven to have a positive and significant influence, it can be interpreted that it means that the higher the 
teacher's creativity, the ability to give birth to new ideas in the teaching and learning process will increase so that the teacher's enthusiasm for work will increase. This is in accordance with Roger's (2002) statement that each individual has a tendency or drive from within him to be creative, realize potential, reveal and activate all of his capacities because of satisfaction with his work.

The results of this study support the findings conducted by Munandar (2012) and Wibisono (2015) which show that teacher creativity has a positive effect on job satisfaction. Likewise with Lakoy's research (2015) also shows that work creativity has an effect on job satisfaction which is proxied by work it self.

\section{The Effect of Teacher Creativity towards the Innovative Behavior Pengaruh Kreatifitas Guru terhadap Perilaku Inovatif}

Teacher creativity has a positive and significant affect on innovative behavior, giving the understanding that the higher teacher's creativity, it can be strength because it is able to create innovative behavior that can create and adopt ideas or new ways to be applied in the implementation of teaching and learning process. According to the statement stated by Timpe (1999) that creative employees who refers to individual development in developing new ideas, products and procedures that are useful for the organization are raw materials because they are able to create innovative behavior.

Teacher who has innovative behavior will take effort to reate and adopt ideas or new method, they will make effort to improve smooth of thinking like the ability of the teachers to be more creative through ideas they apply in the teaching and learning process to attract his students. It is important for teachers to evaluate so they have the ability to understand what the idea which is shared by fellow teachers. It means that the teacher must be flexible to receive input from colleagues to improve the professional competence of the teacher.

The result of this research is suitable with another research conducted by Aprilliyani (2016) creativity of employee hase positive effect on innovative behavior. Likewise, with the Kumalasari and Sya'roni (2017) research Dama and Ogi (2018) also show that creativity has a positive effect on innovativesustainability.

\section{The Effect of Teacher Creativity towards Professional Competence}

Teacher creativity has positive and significan effect towards professional competencem it means that the higher teacher creativity then the teacher ability to produce new idea will get improve as well, so that it will have an impact on the ability or professionalism of the teacher. According to Munandar (2012) explaining that the ability or professionalism of an individual is influenced by the self motivation to be creative in realizing potential, expressing and activating all the capacities they have.

In the learning process, teaching requires smooth of thinking like the ability of the teachers to be more creative through the ideas theyapply in the teaching and learning process in improving the professional competence of the teacher. It is important for teachers to continue evaluating in improving teacher professional competence so that they have the ability to understand what is being suggested by fellow teachers. This means that the teacher must also 
be flexible to receive input from colleagues to improve the professional competence of the teacher.

Professional teacher competence will make teachers improve their abilities, especially how teachers are required to propose new learning methods to improve quality in the teaching and learning process. With the existence of ideas derived from teacher's thinking, it will certainly support the success of the teacher because it will certainly improve the professional competence of the teacher.

The results of this study support the findings of Sya'roni and Sudirham (2016) showing that employee creativity has a large role in increasing professional competence. The results of the research by Dewi and Sudibya (2016) also show the same results that teacher creativity has a positive effect on competence professionalism.

\section{The Effect of Teacher Creativity towards Tecaher Performance}

The results of the study prove that teacher creativity has a positive and significant effect on teacher performance, it can be interpreted that the higher the teacher's creativity, the ability to create new ideas in the teaching and learning process will increase, so that it will have an effect on achieving teacher performance optimally. This statement is in accordance with Guiford (in Munandir, 2009) that creativity is a divergent thinking ability or the thought of exploring various alternative answers to a problem, which is equally true. Furthermore Rogers (in Zulkarnain, 2002) also explains that creativity is a tendency - the tendency of humans to actualize themselves according to their abilities.

It is important for teachers to keep evaluate so that they have the ability to understand what is the idea that is shared by fellow teachers. The ability of teachers is needed especially how teachers are required to propose new learning methods in order to improve quality in the teaching and learning process, so that the resulting performance will be more maximal. With the existence of ideas or ideas that originate from teacher thinking, it will certainly support the success of the teacher because it will certainly improve the teacher's performance optimally.

The results of this study support the findings of Munandar (2009) and Putri (2013) that employee creativity affects employee performance. The research results of Adirestuty and Wirandana (2016) and Dama and Ogy (2018) show that creativity has a positive effect on employee performance. In contrast to the research conducted by Lakoy (2015), creativity actually did not affect employee performance.

\section{The Effect of Work it Self TowardsTeacher Performance}

Work it self also proved to have a positive and significant influence on teacher performance, it means that the more teachers feel satisfied with the work itself, the more it will try in the teaching and learning process, so that it will have an impact on the achievement of teacher performance for more achievement. According to Handoko (2012) that job satisfaction through work itself is an assessment or reflection of workers' feelings for their work. The size of employee job satisfaction on the job itself (work it self) is closely related to the performance produced. 
The proof of the study results provides an indication that it is important for the school to keep evaluating so that the teacher prefers more to the work done, which is trying to make the work in the teaching and learning process carried out by the teachers more attractive. Increasing teacher satisfaction with the work they do will make the teacher try to continuously learn to improve learning.

The results of this study support the findings of Satriowati et al. (2016) that work it self has a positive and significant effect on employee performance. So in the Fitrianasari's research, et.al (2016) that work itself has a positive and significant effect on HR performanc

\section{The Effect of Innovative Behavior towards Tecaher Creativity}

Innovative behavior has a positive and significant effect on teacher performance, giving an understanding that the higher the innovative behavior, the teacher's role in creating and adopting thought ideas in the teaching and learning process is also high, so that the teacher's performance can be maximized. This is in accordance with the statement by Wallace et al. (1999) that innovative work behavior (innoavative behavior) becomes an important part of improving one's performance in preparing competitiveness.

Teacher performance will increase if it is supported by the ability of the teachers in finding new learning methods in the teaching and learning process. The role of the principal is strongly needed to support teachers to agree with innovative ideas that are conveyed by the teachers in supporting maximum performance in the teaching and learning process. For this reason, it is important for teachers to realize innovative ideas that can be applications or programs that can be implemented well in the teaching and learning process.

The results of this study are appropriate withthe findings of Khodijah which shows that innovative behavior has a positive effect on teacher performance. This is the case with the Fatah study (2016) which also shows that innovative behavior has a positive effect on teacher performance

\section{The Effect of Proffesional Competence towards Tecaher Performance}

Professional competence has a positive and significant effect on teacher performance, it means that the higher the professional competence, the higher the level of ability or skill of the teacher, so that it will have an effect on achieving teacher performance optimally in the teaching and learning process. According to Sedarmayanti (2010) the professional competence is a pillar that will place the bureaucracy as an effective control for the government and as a parameter of apparatus skills in achieving one's performance. Furthermore Charles (2000) in Ibrohim (2016) also explained that competence is a rational behavior to achieve the required goals as expected conditions. Professional competence is one of the factors that affect employee performance

This study supports the findings of Subari and Riady (2015) that individual competencies have a positive effect on employee performance. While the research of Ibrohim (2016) and Haryaka (2016) also has similar result that professional competence influences teacher performance 


\section{CONCLUSION}

Based on the research that has been done, the following conclusions can be obtained as follow:

1. The test results show that the creativity of the teacher has a positive effect on work it self, it ccan be seen in the high responses of respondents to the indicators of flexibility of the teachers in receiving good ideas expressed by fellow teachers. The explanation gives an understanding that the higher teacher's creativity, the ability to create new ideas in the teaching and learning process will increase so it will improve the teacher's satisfaction with the work itself

2. Teacher creativity has a positive and significant effect on innovative behavior, as seen in the respondents' high responses to the teacher's flexibility indicators in receiving good ideas expressed by fellow teachers so that it will make the teacher's innovative behavior. The explanation can be interpreted that the higher the creativity of the teacher, it becomes a strength because it is able to create innovative behavior to create and adopt ideas or new method to be applied in the implementation of the teaching and learning process.

3. Teacher creativity has a significant positive effect on professional competence, as seen in the respondents' high responses to the teacher's flexibility indicators in receiving good ideas expressed by fellow teachers so that they will improve the teacher's professional competence.

4. Teacher creativity has a significant positive effect on teacher performance, as seen in the high responses of respondents to the teacher's flexibility indicators in accepting good ideas expressed by fellow teachers to maximize teacher performance. The elaboration can be interpreted that the higher creativity of the teacher, the ability to create new ideas in the teaching and learning process will increase, so that it will have an impact on achieving teacher performance optimally.

5. Teacher creativity has a positive and significant effect on innovative behavior, as seen in the respondents' high responses to the teacher's flexibility indicators in receiving good ideas expressed by fellow teachers so that it will make the teacher's innovative behavior. The explanation can be interpreted that the higher the teacher's creativity becomes strength since it is able to create innovative behavior to create and adopt ideas or new method to be applied in the implementation of the teaching and learning process.

6. Teacher creativity has a significant positive effect on professional competence, as seen in the high respondent's response to the teacher's flexibility indicators in accepting good ideas expressed by fellow teachers so that they will improve to the teacher's professional competence.

7. Teacher creativity has a significant positive effect on teacher performance, as seen in the high response of respondents to the teacher's flexibility indicators in accepting good ideas expressed by fellow teachers to maximize teacher performance. The explanation can be interpreted that the higher creativity of the teacher, the ability to create new ideas in the teaching and learning process will increase, so that it will have an impact on achieving teacher performance optimally. 
8. Teacher creativity has a significant positive effect on professional competence, as seen in the respondents' high responses to the teacher's flexibility indicators in accepting good ideas expressed by fellow teachers so that they will improve to the teacher's professional competence.

9. Teacher creativity has a significant positive effect on teacher performance, as seen in the high responses of respondents to the teacher's flexibility indicators in accepting good ideas expressed by fellow teachers so as to maximize teacher performance. The explanation can be interpreted that the higher the creativity of the teacher, the ability to create new ideas in the teaching and learning process will increase, so that it will have an impact on achieving teacher performance optimally.

10. Work it self also proved to has a positive and significant effect on teacher performance, as seen in the high responses of respondents to the teacher's flexibility indicators in accepting good ideas expressed by fellow teachers. The explanation means that the more teachers are satisfied with the work itself, the more they will try in the teaching and learning process, so that it will has an impact on the achievement of teacher performance to be more accomplished.

11. Innovative behavior has a positive and significant effect on teacher performance, as seen by the high ability to introduce innovative ideas. The explanation provides an understanding that the higher the innovative behavior, the teacher's role in creating and adopting ideas while in teaching and learning process is also high, then it will be able to improve teacher performance optimally.

12. Professional competency has a significant positive effect on teacher performance, as seen with the ability of schools to implement in learning strategies. The explanation can be interpreted that the higher the professional competence, the higher level of ability or skill of the teacher, so that it will have an impact on the maximum achievement of teacher performance in the teaching and learning process.

13. Work it self is able to be an intervening variable between teacher creativity and teacher performance, it means that the higher the teacher's ability to produce new ideas in the teaching and learning process, the higher the teacher's satisfaction with the work itself, so the teacher's performance can be optimum .

14. Innovative behavior can be an intervening variable between teacher creativity and teacher performance.

15. Innovative behavior has a positive and significant effect on teacher performance, as seen by the high ability to introduce innovative ideas. The explanation provides an understanding that the higher the innovative behavior, the teacher's role in creating and adopting ideas in the teaching and learning process get higher, so that it will be able to improve teacher performance optimally.

16. Professional competency has a significant positive effect on teacher performance, as seen with the ability of schools to implement learning strategies. The explanation can be interpreted that the higher of professional competence, the higher the level of ability or skill of the teacher, sao that it will has an impact on the maximum achievement of teacher performance in the teaching and learning process. 
17. Work it self is able become an intervening variable between teacher creativity and teacher performance, meaning that the higher the teacher's ability to produce new ideas in the teaching and learning process, the higher the teacher's satisfaction with the work itself, so that the teacher's performance can be maximized.

18. Innovative behavior has a positive and significant effect on teacher performance, as seen by the high ability to introduce innovative ideas. The explanation gives an understanding that the higher innovative behavior, the role of the teacher to create and adopt ideas in the teaching and learning process is also high, so that it will be able to improve teacher performance optimally.

19. Professional competencies have a significant positive effect on teacher performance, as seen with the ability of schools to implement learning strategies. The explanation can be interpreted that the higher professional competence, the higher the level of ability or skill of the teacher, so that it will has an impact on the maximum achievement of teacher performance in the teaching and learning process.

20. Work it self can be an intervening variable between teacher creativity and teacher performance, meaning that the higher the teacher's ability to produce new ideas in the teaching and learning process, the higher the teacher's satisfaction with the work itself, so that the teacher performance maximally.

21. Innovative behavior can be an intervening variable between teacher creativity and teacher performance.

22. Professional competence can be an intervening variable between teacher creativity and teacher performance, it means that the higher the teacher's ability to produce new ideas in the learning process of competency or the professionalism of teachers will increase so that the impact on the achievement of teacher performance optimally

\section{REFERENCES}

Adirestuty, Fitranty dan Eri Wirandana, 2016. Pengaruh self efficacy guru dan kreativitas guru terhadap motivasi belajar siswa dan implikasinya terhadap prestasi belajar pada mata pelajaran Ekonomi. Social Science Education Journal. Vol. 3 No. 2

Depdiknas. 2005. Peraturan pemerintah RI nomor 19 tahun 2005 tentang standar nasional pendidikan

Mendiknas. 2007. Peraturan Menteri Pendidikan Nasional Nomor 16 Tahun 2007 tentang Kompetensi Guru. Jakarta: Depdiknas

Ghozali, Imam. 2013. Aplikasi Analisis Multivariate Dengan Program SPSS. Badan Penerbit Universitas Diponegoro. Semarang

Hartanti, Astrid Setianing dan Tjutju Yuniarsih, 2018. Pengaruh kompetensi professional guru dan motivasi kerja terhadap kinerja guru di Sekolah Menengah Kejuruan. Jurnal Pendidikan Manajemen Perkantoran. Vol. 1 No. 2 Hal : 197-27

Haryaka, 2016. Pengaruh kompetensi professional dan komitmen organizational terhadap kinerja guru di moderasi Budaya organizational. Jurnal. Manajemen Bisnis Vol. 3 No. 2 
Hughes, R. L., Ginnette, R. C., \& Curphy, G. J. 2012. Leadership: enhancing the lessons of experience. Leadership: enhancing the lessons of experience. https://doi.org/10.1017/ CBO9781107415324.004

Ibrohim. 2016. Pengaruh kompetensi professional dan motivasi kerja terhadap kinerja guru dimoderasi kepemimpinan kepala sekolah. Jurnal. Manajemen Bisnis Vol. 3 No. 2

Juwono, Onny dan Yuliana Wangsadinata, 2010. Kreativitas, gaya kepemimpinan dan kompetensi dalam membentuk kepuasan kerja karyawan. Journal The Winners, Vol. 11 No. Hal : 55-65

Lakoy, Amanda Carolina, 2015 Pengaruh komunikasi, kerja sama kelompok dan kreativitas terhadap kinerja karyawan. Jurnal EMBA. Vol. 3 No. 3 Hal 981-991 ISSN 2303-11

Mendiknas. 2011. Peraturan Menteri Pendidikan Nasional Nomor 16 Tahun 2011 tentang Kompetensi Guru. Jakarta: Depdiknas

Mulyasa. 2005, Menjadi Kepala Sekolah ProfessionalDalam Konteks Mensukseskan MBS Dan KBK.Bandung: Remaja Rosdakarya

Munandar, 2009, Analisis pengaruh kreativitas dan perilaku inovatif terhadap kinerj karyawan. Jurnal Manajemen. Vol. X No.1

Muslikh, 2012, Upaya mengembangkan kreativitas untuk meningkatkan daya saing dan kinerja bisnis UMKM, Jurnal Manajemen dan Bisnis. Vol. 1 No. 1

Raharjo, Wiryo dan Y Sutomo. 2016 Pengaruh motivasi dan kompetensi professional terhadap kinerja guru dimoderasi budaya organisasional. Jurnal. Manajemen Bisnis Vol. 3 No. 2

Rahayu, Sri. 2011, Pengaruh komitmen professional dan motivasi intrinsic terhadap kinerja guru. Jurnal Manajemen Bisnis Vol. 3 No. 3

Simamora, Henry, 2013, Manajemen Sumber Daya Manusia ${ }_{2}$ STIE YKPN, Yogyakarta

Subari, Subari and Hanes Riady, 2015, Influence of training, competence and motivation on employee performance, moderated by internal communication. American Journal of Business and Management. Vol. 4 No. 3 PP : 133-145

Triyanto, Arif, 2014. Pengaruh kompetensi dan penghargaan terhadap motivasi kerja karyawan. Jurnal Paradigma Vol. 12 No. 01 ISSN : 1693-0827

Tunjungsari, P. (2011). Pengaruh Stress Kerja Terhadap Work it self Karyawan Pada Kantor Pusat PT. Pos Indonesia (Persero) Bandung. Universitas Komputer Indonesia, 1(1), 1-14

Uno, Hamzah B. \& Nina Lamatenggo. 2013. Teori Kinerja dan Pengukurannya. Jakarta:Bumi Aksara

Wijayanto, Japerdi dan Lucky O. H Datulong, 2017. Pengaruh pelatihan, kompetensi dan motivasi terhadap kinerja karyawan pada PT. Plasa Multi Krindo Manado. Jurnal EMBA. Vol. 5 No. 2 Hal. 3048-3057 ISSN 2303-1174 